\title{
A Systematic Review Evaluating the Efficacy of Intra-Ovarian Infusion of Autologous Platelet- Rich Plasma in Patients With Poor Ovarian Reserve or Ovarian Insufficiency
}

\author{
Soumya R. Panda ${ }^{1}$, Shikha Sachan ${ }^{2}$, Smrutismita Hota ${ }^{3}$ \\ 1. Obstetrics and Gynaecology, All India Institute of Medical Sciences, Mangalagiri, Guntur, IND 2. Obstetrics and \\ Gynaecology, Institute of Medical Sciences, Banaras Hindu University, Varanasi, IND 3. Radiodiagnosis and Imaging, \\ All India Institute of Medical Sciences, Mangalagiri, Guntur, IND
}

Corresponding author: Soumya R.Panda,drsome4141@gmail.com

\begin{abstract}
The emergence of autologous platelet-rich plasma (PRP) therapy reflects a break-through for infertile patients with premature ovarian failure. To study the efficacy of intra-ovarian infusion of autologous PRP on the improvement of ovarian reserve parameters and the subsequent artificial reproductive technique (ART) cycle outcomes in infertile women with poor ovarian reserve or premature ovarian insufficiency, a systematic search in electronic databases like Medline (through PubMed), Embase, Scopus, Web of Science, and Cochrane was done using relevant search terms. Except for case series, case reports, and review articles, all other types of studies, those evaluated for the effects of intra-ovarian infusion of PRP in subfertile women for decreased ovarian reserve (DOR) or premature ovarian insufficiency (POI) were included in our systematic review. The data were extracted from each eligible study and cross-checked by two authors. Intraovarian PRP infusion appears to be effective in ovarian rejuvenation, and the results of the subsequent intracytoplasmic sperm injection (ICSI) cycle are encouraging. PRP intervention was found to be beneficial in terms of an improvement in ovarian reserve parameters (increase in serum anti-mullerian hormone or antral follicle count or decrease in serum follicular stimulating hormone). ICSI cycle performance in terms of the total number of oocytes retrieved, number of two-pronuclei embryos, fertilization rate, number of cleavage stage embryos, number of good quality embryos, and cycle cancellation rate were found to be improved after intra-ovarian PRP infusion as compared to their previous cycle without PRP infusion.
\end{abstract}

Review began $11 / 30 / 2020$ Review ended 12/06/2020 Published 12/12/2020

๑) Copyright 2020

Panda et al. This is an open access article distributed under the terms of the Creative Commons Attribution License CC-BY 4.0., which permits unrestricted use, distribution, and reproduction in any medium, provided the original author and source are credited.

Categories: Obstetrics/Gynecology

Keywords: decreased ovarian reserve, platelet-rich plasma, premature menopause, premature ovarian insufficiency, prp

\section{Introduction And Background}

A steady decline in the quantity and quality of the oocyte reserves associated with ovarian ageing acts as the principal limiting factor for success in both spontaneous conception and assisted reproductive technology (ART) [1-2]. These aged oocytes are also more prone to errors in deoxyribonucleic acid (DNA) synthesis and cell division, resulting in increased rates of aneuploidy and congenital defects in the resulting conceptions [3]. In the absence of any effective treatment to prevent, delay, or reverse ovarian senescence, various therapeutic strategies like antioxidant dietary supplements containing vitamins $\mathrm{C}$ and $\mathrm{E}$, melatonin, dehydroepiandrosterone (DHEA), and coenzyme Q10 have been used to address this issue [4-8]. However, evidence in their support are inconclusive, and their overall effectiveness remains sparse [9-10]. At present, treatment strategies to tackle infertility associated with ovarian insufficiency are commonly in vitro fertilization (IVF) treatment in conjunction with an oocyte donation program or adoption [11-16]. Of late, ovarian function restoration approaches are being investigated rigorously, which can result in healthy, genetically linked offspring in these patients. The successful use of platelet-rich plasma (PRP) in regenerative medicine has led investigators to study its effect in the treatment of conditions like decreased ovarian reserve, premature ovarian failure, etc. [17]. The emergence of autologous PRP therapy reflects a breakthrough approach, showcasing promising results. However, at present, there are very few studies addressing this issue.

This systematic review was conducted to study the effects of intra-ovarian instillation of autologous PRP on ovarian rejuvenation. It was designed to study the efficacy of intra-ovarian infusion of autologous plateletrich plasma (PRP) on the improvement of ovarian reserve parameters and the subsequent artificial reproductive technique (ART) cycle outcomes in infertile women with poor ovarian reserve or premature ovarian insufficiency.

\section{Review}

\section{Methodology}


This systematic review was done to assess the effectiveness of intra-ovarian infusion of PRP in sub-fertile women in terms of improvement in ovarian reserve parameters and outcomes after assisted reproduction. We followed the recommendations of the Cochrane Handbook for Systematic Reviews of Interventions and Preferred Reporting Items for Systematic Reviews and Meta-Analyses (PRISMA) guidelines (Figure 1).
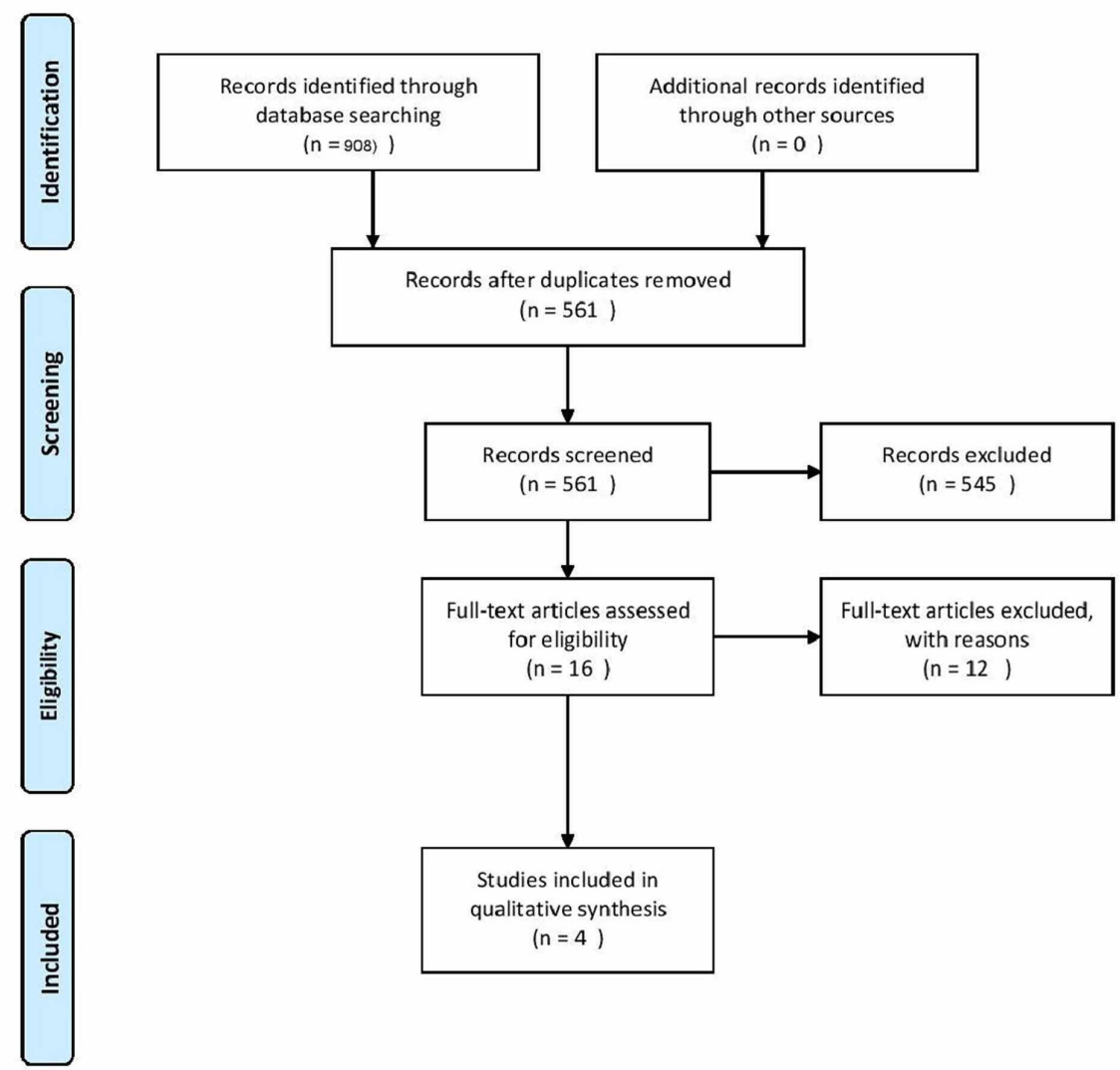

\section{FIGURE 1: Flow of information through the different phases of the systematic review (according to PRISMA)}

PRISMA: Preferred Reporting Items for Systematic Reviews and Meta-Analyses

A systematic search in electronic databases like Medline (through PubMed), Embase, Scopus, Web of Science, and Cochrane was performed from January 2000 to November 2020. We used search terms like: ("In Vitro Fertilization” OR “IVF” OR “Intracytoplasmic sperm injection” OR “ICSI” OR “Embryo transfer” AND “Platelet-rich plasma” OR “PRP” OR “Autologous platelet-rich plasma” OR "Platelet-rich plasma” and “premature ovarian failure” OR “decreased ovarian reserve” OR "premature menopause” etc). Literature published only in the English language was included in our study.

\section{Inclusion and exclusion criteria}

All studies that evaluated the effects of intra-ovarian infusion of PRP in subfertile women for decreased ovarian reserve (DOR) or premature ovarian insufficiency (POI) were included in our systematic review. This review included all types of studies, including case-control studies, cohort studies, or clinical trials. Data regarding ovarian reserve parameters and the intracytoplasmic sperm injection (ICSI)/in vitro fertilization (IVF) cycle characteristics were analyzed in this systematic review. Case series, case reports, and review articles were excluded from our systematic review.

\section{Study selection, data extraction, and quality appraisal}

Two authors (S.R.P and S.H.) independently scrutinized the titles and abstracts of the electronic searches according to the predefined eligibility criteria. For relevant studies, full articles were retrieved. The data were extracted from each eligible study and cross-checked by the two authors (S.R.P and S.H.) and by the third author (S.S.). The quality of included studies was assessed based on the criterion provided using the Risk Of Bias In Non-randomized Studies - of Interventions (ROBINS-I) tools for assessing the risk of bias of prospective observational studies [18]. We found four studies to have a low risk of bias. This has been shown in the Appendix. 


\section{Cureus}

\section{Meta-analysis}

A meta-analysis was planned; however, due to the paucity of available studies and the heterogeneity of the included outcomes, it was deemed inapplicable.

\section{Results}

Summary of the Literature Search

The initial electronic literature search yielded 908 publications. After excluding duplicates and irrelevant publications, we found 16 potentially eligible studies. After reading the full text of those 16 articles, 12 articles (three case series, two case reports, one article with insufficient data, one study involving in-vitro experimental design, and five review articles) were excluded. Finally, four studies were included in our systematic review [19-22]. The flow diagram of the literature search and selection of studies is shown in Figure 1.

\section{Study Characteristics}

In this systematic review, we have included four studies that evaluated the effectiveness of PRP in infertile women diagnosed with decreased ovarian reserve or premature ovarian failure or menopause. Table 1 outlines the characteristics of all included studies [19-22].

\begin{tabular}{|c|c|c|c|c|c|c|c|c|}
\hline $\begin{array}{l}\text { SI } \\
\text { no. }\end{array}$ & Study & Country & Study design & Population & $\begin{array}{l}\text { Sample } \\
\text { size }\end{array}$ & Intervention & Control & Outcome measures \\
\hline 1. & $\begin{array}{l}\text { Cakiroglu et } \\
\text { al. } 2020 \text { [19]. }\end{array}$ & Turkey & $\begin{array}{l}\text { Quasi- } \\
\text { experimental- } \\
\text { (uncontrolled } \\
\text { before and } \\
\text { after studies) }\end{array}$ & Infertile POI & 311 & $\begin{array}{l}\text { Injection of } \\
\text { approximately 2-4 } \\
\text { ml PRP into each } \\
\text { ovary was } \\
\text { performed under } \\
\text { transvaginal } \\
\text { ultrasound } \\
\text { guidance. }\end{array}$ & - & $\begin{array}{l}\text { Number of retrieved oocytes, } \\
\text { number of mature oocytes, } \\
\text { number of } 2 \text { pronuclei embryos, } \\
\text { fertilization rate, number of } \\
\text { cleavage stage embryos }\end{array}$ \\
\hline 2. & $\begin{array}{l}\text { Melo et al. } \\
2020 \text { [20]. }\end{array}$ & Venezuela & $\begin{array}{l}\text { Non- } \\
\text { randomized } \\
\text { clinical trial }\end{array}$ & $\begin{array}{l}\text { Infertile patients } \\
\text { planning for IUI/IVF with } \\
\text { (i) age } 38 \text { years old and } \\
\text { above, (ii) baseline } \mathrm{FSH} \text {, } \\
\text { day } 3 \text { of the menstrual } \\
\text { cycle) }>12 \mathrm{mlU} / \mathrm{mL} \text {, (iii) } \\
\text { AMH }<0.8 \mathrm{ng} / \mathrm{mL}\end{array}$ & $\begin{array}{l}\text { Cases- } \\
46 \\
\text { Controls- } \\
37\end{array}$ & $\begin{array}{l}\text { injection received } \\
\text { once between } \\
\text { days } 7 \text { and } 9 \text { of } \\
\text { the menstrual } \\
\text { cycle for three } \\
\text { consecutive } \\
\text { cycles (cycles } 1 \text {, } \\
2 \text {, and 3). }\end{array}$ & $\begin{array}{l}\text { No } \\
\text { intervention }\end{array}$ & $\begin{array}{l}\text { Primary outcome: AFC and serum } \\
\text { levels of FSH and AMH as a } \\
\text { measure of ovarian reserve. } \\
\text { Secondary outcome: number of } \\
\text { oocytes collected and fertilization } \\
\text { rates during IVF/ICSI; rates of } \\
\text { biochemical, clinical, and ongoing } \\
\text { pregnancy per participant; and } \\
\text { rates of first-trimester miscarriage } \\
\text { and live birth }\end{array}$ \\
\hline 3. & $\begin{array}{l}\text { Sfakianoudis } \\
\text { et al. } 2020 \\
\text { [21]. }\end{array}$ & Greece & $\begin{array}{l}\text { Quasi- } \\
\text { experimental- } \\
\text { (uncontrolled } \\
\text { before and } \\
\text { after studies) }\end{array}$ & $\begin{array}{l}\text { Four pilot studies were } \\
\text { conducted on POR, } \\
\text { POI, perimenopause, } \\
\text { and menopause }\end{array}$ & $\begin{array}{l}30 \\
\text { subjects } \\
\text { for each } \\
\text { cohort }\end{array}$ & $\begin{array}{l}\text { Injection of } \\
\text { approximately } 4 \\
\text { ml PRP into each } \\
\text { ovary was } \\
\text { performed under } \\
\text { transvaginal } \\
\text { ultrasound } \\
\text { guidance. }\end{array}$ & & $\begin{array}{l}\text { AFC, AMH, and oocyte yield in the } \\
\text { ICSI-ET cycle, mature metaphase } \\
\text { II (MII) oocyte yield in the ICSI-ET } \\
\text { cycle post-PRP, number of } \\
\text { resulting embryos, and cycle } \\
\text { cancellation rate. }\end{array}$ \\
\hline 4. & $\begin{array}{l}\text { Sills et al. } \\
2020 \text { [22]. }\end{array}$ & USA & $\begin{array}{l}\text { Quasi- } \\
\text { experimental- } \\
\text { (uncontrolled } \\
\text { before and } \\
\text { after studies) }\end{array}$ & $\begin{array}{l}\text { POR with at least one } \\
\text { previous failed IVF cycle } \\
\text { in perimenopausal or } \\
\text { menopausal age }\end{array}$ & 182 & $\begin{array}{l}1 \mathrm{~mL} \text { of activated } \\
\text { PRP via } \\
\text { transvaginal USG } \\
\text { guidance }\end{array}$ & & Serum AMH \& FSH \\
\hline
\end{tabular}

\section{TABLE 1: Characteristics of included studies}

POI: premature ovarian insufficiency; POR: poor ovarian response; PRP: platelet-rich plasma; FSH: follicle-stimulating hormone; AMH: anti-Müllerian hormone; IVF: in vitro fertilization; USG: ultrasonography; AFC: antral follicle count; ICSI: intracytoplasmic sperm injection; ET: embryo transfer 
Out of four included studies, one was a non-randomized clinical trial and three were quasi-experimental studies (uncontrolled before and after studies). All studies compared the ovarian reserve parameters (AMH, FSH, and antral follicle count (AFC)) before and after PRP infusion. The analysis of the outcome of the ICSI cycle was done in three out of four studies [19-21]. The method of preparation of PRP and time schedule of injection are described in Table 2.

\begin{tabular}{|c|c|c|c|c|}
\hline no. & Study & $\begin{array}{l}\text { IIme schedule of } \\
\text { injection }\end{array}$ & $\begin{array}{l}\text { Time schedule of } \\
\text { reassessment of ovarian } \\
\text { reserve parameters and/or } \\
\text { starting of IVF cycle }\end{array}$ & Method of PRP preparation \\
\hline 1 & $\begin{array}{l}\text { Cakıroglu et } \\
\text { al.2020 [19]. }\end{array}$ & $\begin{array}{l}\text { timed randomly in } \\
\text { women who were } \\
\text { amenorrheic, while } \\
\text { in women who } \\
\text { reported } \\
\text { oligomenorrhea, } \\
\text { PRP was injected } \\
\text { within } 10 \text { days } \\
\text { after completion of } \\
\text { menstrual } \\
\text { bleeding. }\end{array}$ & $\begin{array}{l}\text { On the second menstrual } \\
\text { cycle (on the } 2^{\text {nd }} \text { to } 4^{\text {th }} \text { day of } \\
\text { menses) after the PRP } \\
\text { procedure, AFC and serum } \\
\text { AMH and FSH levels were re- } \\
\text { assessed. Those who were } \\
\text { found to have antral follicle(s) } \\
\text { at that point were started on } \\
\text { controlled ovarian } \\
\text { hyperstimulation (COH), while } \\
\text { those who did not were } \\
\text { followed monthly, up to } 6 \\
\text { months, and underwent COH } \\
\text { when/if they developed antral } \\
\text { follicle(s). }\end{array}$ & $\begin{array}{l}\text { After blood collection, the tubes were centrifuged at } 830 \mathrm{~g} \\
\text { for } 8 \text { minutes. Then, a } 16 \text { G needle connected to a } 5 \mathrm{ml} \\
\text { syringe was inserted into the tube and advanced to the } \\
\text { buffy coat layer. The PRP was collected by rotating the } \\
\text { needle tip. After collecting approximately } 2-4 \mathrm{cc} \text { PRP from } \\
\text { the first tube, the second tube was processed similarly (a } \\
\text { total of } 4-8 \mathrm{cc} \text { PRP was collected). The collected solution } \\
\text { was transferred to the re-suspension tube and shaken } \\
\text { gently for } 30 \mathrm{~s}-1 \mathrm{~min} \text {. }\end{array}$ \\
\hline 2 & 2020 [20]. & $\begin{array}{l}\text { opted for PRP } \\
\text { injections received } \\
\text { treatment once } \\
\text { between days } 7 \\
\text { and } 9 \text { of the } \\
\text { menstrual cycle for } \\
\text { three consecutive } \\
\text { cycles (cycles } 1,2 \text {, } \\
\text { and 3). }\end{array}$ & $\begin{array}{l}\text { Following the completion of } \\
\text { treatment with PRP, } \\
\text { participants were advised to } \\
\text { undergo IVF/ICSI, IUI, or } \\
\text { timed intercourse as soon as } \\
\text { the next menstrual cycle } \\
\text { started. }\end{array}$ & $\begin{array}{l}\text { A total of } 5 \text { blood collection tubes containing sodium } \\
\text { citrate } 3.8 \% \text { were filled with } 4.5 \mathrm{~mL} \text { of blood each and } \\
\text { centrifuged at } 270 \mathrm{~g} \text { for } 10 \mathrm{~min} \text {. Following centrifugation, } \\
100 \mu \mathrm{L} \text { of the platelet-rich supernatant were transferred } \\
\text { from each of } 4 \text { of the original blood tubes and mixed with } \\
0.1 \mathrm{~mL} \text { of } 10 \% \text { calcium chloride. The blood in the } \\
\text { remaining fifth tube was not mixed with calcium chloride to } \\
\text { allow for quantification of the total number of platelets in } \\
\text { the sample. On the day of blood collection (i.e. day } 7,8 \text {, or } \\
9 \text { of the cycle), } 200 \mu \mathrm{L} \text { of PRP were injected into the cortex } \\
\text { of each ovary using a single lumen aspiration needle. }\end{array}$ \\
\hline 3 & $\begin{array}{l}\text { Stakıanoudis } \\
\text { et al. } 2020 \\
\text { [21]. }\end{array}$ & $\begin{array}{l}\text { For women } \\
\text { presenting with } \\
\text { menstrual cycles, } \\
\text { such as POR and } \\
\text { perimenopausal } \\
\text { women PRP } \\
\text { administration was } \\
\text { done on day-3 of } \\
\text { the menstrual } \\
\text { cycle. For POI and } \\
\text { menopausal } \\
\text { women being } \\
\text { amenorrheic, PRP } \\
\text { administration was } \\
\text { performed on a } \\
\text { random day. }\end{array}$ & $\begin{array}{l}\text { PRP administration took } \\
\text { place during the early } \\
\text { follicular phase of the cycle } \\
\text { PRP intraovarian infusion } \\
\text { treatment was performed at } \\
\text { least two months following } \\
\text { the last failed ICSI-ET cycle. } \\
\text { In the third menstrual cycle } \\
\text { post-PRP treatment, all } \\
\text { participants received the } \\
\text { GnRH antagonist protocol } \\
\text { and underwent an ICSI-ET } \\
\text { fresh cycle. }\end{array}$ & $\begin{array}{l}\text { Blood samples were collected from the median } \\
\text { antebrachial vein. PRP was prepared according to the } \\
\text { manufacturer's instructions employing a RegenACR } ® \text {-C Kit } \\
\text { (Regen Laboratory, Le Mont-sur-Lausanne, Switzerland). } \\
\text { Approximately } 60 \mathrm{ml} \text { of the patient's peripheral blood was } \\
\text { required in order to yield the required volume of PRP. The } \\
\text { initial concentration of platelets in peripheral blood was } \\
\text { approximately } 250,000 \text { platelets/ } \mu \mathrm{L} \text {. The goal } \\
\text { concentration of platelets in PRP was approximately } \\
1,000,000 \text { platelets/ } \mu \mathrm{L} \text {. According to our protocol, prepared } \\
\text { PRP could be stored for one hour at a temperature of } 4{ }^{\circ} \mathrm{C} \\
\text { if required. However, regarding the vast majority of the } \\
\text { participants, PRP intraovarian infusion was performed } \\
\text { immediately following preparation. }\end{array}$ \\
\hline 4 & 2020 [22]. & $\begin{array}{l}\text { All patients had } \\
\text { testing for serum } \\
\text { AMH, estradiol } \\
\text { (E2), and FSH at } \\
\text { approximately } \\
\text { two-week intervals }\end{array}$ & & $\begin{array}{l}\text { Approximately } 8-10 \mathrm{~mL} \text { whole blood was collected by } \\
\text { peripheral venipuncture from each patient using a } 21 \mathrm{G} \\
\text { butterfly catheter affixed via vacutainer to negative } \\
\text { pressure-receiving tubes (RegenLab; Mont-Sur Lausanne, } \\
\mathrm{CH} \text { ). Samples were immediately labeled and placed in } \\
\text { room temperature centrifuge set to } 1500 \mathrm{~g} \times 5 \mathrm{~min} \text {. } \\
\text { Processed blood was then fractionated, and erythrocytes } \\
\text { were trapped beneath while lower density components } \\
\text { settled atop the separator gel. Less than } 3 \mathrm{~mL} \text { of } \\
\text { supernatant (corresponding to relatively platelet-poor }\end{array}$ \\
\hline
\end{tabular}




\section{Cureus}

after ovarian PRP.

plasma fraction) was then aspirated off the top of each column before recapping the vial for gentle tube inversion/resuspension, as per supplier instructions. PRP activation was achieved with calcium gluconate.

\section{TABLE 2: Method of preparation of platelet-rich plasma and time schedule of injection}

POI: premature ovarian insufficiency; POR: poor ovarian response; PRP: platelet-rich plasma; FSH: follicle-stimulating hormone; AMH: anti-Müllerian hormone; IVF: in vitro fertilization; AFC: antral follicle count; ICSI: intracytoplasmic sperm injection; ET: embryo transfer

\section{Ovarian reserve parameters}

Serum Anti-Mullerian Hormone (AMH)

As shown in Table 3, the study conducted by Sfakianoudis et al. [21] showed an increase in serum AMH level after treatment with PRP for the cohorts of poor ovarian response, premature ovarian insufficiency, perimenopause, and menopause, respectively. The difference was found to be statistically significant with pvalues of less than $<0.0001$ in all groups.

\begin{tabular}{|c|c|c|c|c|c|c|c|c|}
\hline & & $\begin{array}{l}\text { Cakiroglu } \\
\text { et al. } 2020 \\
\text { [19]. } \\
(\mathrm{N}=311)\end{array}$ & $\begin{array}{l}\text { Melo et al } \\
2020 \text { [20]. } \\
(\mathrm{N}=46)\end{array}$ & $\begin{array}{l}\text { Sfakianoudis et al.2020 } \\
\text { [21]. (pilot of poor } \\
\text { ovarian response) }(\mathrm{N}=30)\end{array}$ & $\begin{array}{l}\text { Sfakianoudis et al., } 2020 \\
\text { [21]. (premature ovarian } \\
\text { insufficiency pilot) ( } \mathrm{N}=30 \text { ) }\end{array}$ & $\begin{array}{l}\text { Sfakianoudis et al. } \\
2020 \text { [21]. } \\
\text { (perimenopause pilot) } \\
(\mathrm{N}=29)\end{array}$ & $\begin{array}{l}\text { Sfakianoudis et al. } \\
2020 \text { [21]. } \\
\text { (menopause pilot) } \\
(\mathrm{N}=25)\end{array}$ & $\begin{array}{l}\text { Sills et al. } \\
2020 \text { [22]. } \\
(\mathrm{N}=182)\end{array}$ \\
\hline \multirow{3}{*}{$\begin{array}{l}\text { AMH } \\
\text { (ng/mL) }\end{array}$} & Pretreatment & $0.13 \pm 0.16$ & $\begin{array}{l}0.62^{*}(0.47 \\
\text { to } 0.76)\end{array}$ & $0.66 \pm 0.20$ & $0.168 \pm 0.04$ & $0.94 \pm 0.29$ & $0.12 \pm 0.04$ & $\begin{array}{l}0.18 \pm \\
0.25\end{array}$ \\
\hline & Posttreatment & $0.18 \pm 0.18$ & $\begin{array}{l}1.01^{*}(0.9 \\
\text { to } 1.3)\end{array}$ & $1.14 \pm 0.26$ & $0.57 \pm 0.05$ & $1.26 \pm 0.26$ & $0.40 \pm 0.13$ & $\begin{array}{l}0.24 \pm \\
0.05\end{array}$ \\
\hline & $\mathrm{p}$-value & $<0.01$ & $<0.001$ & $<0.0001$ & $<0.0001$ & $<0.0001$ & $<0.0001$ & 0.0016 \\
\hline \multirow{3}{*}{$\begin{array}{l}\text { FSH } \\
\text { (mlU/L) }\end{array}$} & Pretreatment & $41.9 \pm 24.7$ & $\begin{array}{l}13.6^{*} \\
(12.9 \text { to } \\
17.5)\end{array}$ & $10.71 \pm 1.62$ & $49.82 \pm 6.19$ & $18.47 \pm 2.47$ & $80.69 \pm 5.61$ & $\begin{array}{l}52.67 \pm \\
4.64\end{array}$ \\
\hline & Posttreatment & $41.6 \pm 24.7$ & $\begin{array}{l}9.07^{*}(8.3 \\
\text { to } 10.5)\end{array}$ & $8.95 \pm 1.40$ & $36.16 \pm 6.6$ & $15.85 \pm 3.69$ & $48.03 \pm 5.90$ & $\begin{array}{l}64.68 \pm \\
5.5\end{array}$ \\
\hline & $p$-value & $p=0.87$ & $<0.001$ & 0.1342 & $<0.0001$ & 0.0024 & $<0.0001$ & $<0.0001$ \\
\hline \multirow{3}{*}{$\begin{array}{l}\text { Total } \\
\text { AFC (n) }\end{array}$} & Pretreatment & $0.5 \pm 0.5$ & $4^{*}(3$ to 5$)$ & $2.63 \pm 0.93$ & $0 \pm 0$ & $1.43 \pm 0.55$ & $0 \pm 0$ & \\
\hline & Posttreatment & $1.7 \pm 1.4$ & $7^{*}(6$ to 8$)$ & $5.20 \pm 1.35$ & $1.39 \pm 0.37$ & $3.64 \pm 0.78$ & $1.23 \pm 0.46$ & \\
\hline & $\mathrm{p}$-value & $<0.01$ & $<0.001$ & $<0.0001$ & $<0.0001$ & $<0.0001$ & $<0.0001$ & \\
\hline
\end{tabular}

\section{TABLE 3: Ovarian reserve parameters}

FSH: follicle-stimulating hormone; AMH: anti-Müllerian hormone; AFC: antral follicle count

Similarly, Melo et al. found an increase in the median value of the post-treatment level of serum AMH (in $\mathrm{ng} / \mathrm{ml}$ ) from the respective pretreatment level [20]. The median difference was 0.5 (0.43 to 0.57$)$, and the increase in serum AMH with PRP infusion was found to be statistically significant (p-value $<0.001$ ). This has been depicted in Table 3.

At the same time in the study by Cakiroglu et al. [19] and Sills et al. [22], the level of serum AMH was also found to be increased (Table 3) after intra-ovarian PRP infusion with a statistically significant difference (pvalues of $<0.01$ and 0.0016 for the respective studies). Sills et al. [22] found platelet count as a parameter likely to predict $\mathrm{AMH}$ response to intra-ovarian PRP injection. 
In the study by Sfakianoudis et al., the serum FSH levels were decreased post-treatment with PRP for all the studied cohorts [21]. Except for the cohort of women with poor ovarian reserve (p-value=0.1342), all other cohorts were having a statistically significant decrease in serum FSH level (p-values of $<0.0001,0.0024$, and $<0.0001$ for cohorts of premature ovarian insufficiency, perimenopause, and menopause respectively).

Melo et al. found a decrease in the median of post-treatment values of serum FSH with a median difference of $-5.5(-6.3$ to -4.9$)$ and the difference was found to be statistically significant ( p-value -0.001) [20].

In the study by Cakiroglu et al., the average of pretreatment and post-treatment values of serum FSH (all values in $\mathrm{mIU} / \mathrm{ml}$ ) were found to be $41.9 \pm 24.7$ and $41.6 \pm 24.7$ [19]. But this decrease in serum FSH levels was not statistically significant (p-value=0.87).

Moreover, Sills et al. found an increase in the post-treatment serum FSH value of $64.68 \pm 5.5$ from its pretreatment value of $52.67 \pm 4.64$ with a statistically significant difference (p-value<0.0001) [22].

These findings are tabulated in Table 3 .

Antral Follicle Count (AFC)

As far as antral follicle count is concerned, the studies by Sfakianoudis et al. [21] (in all of their studied cohorts) and Melo et al. [20] found an increase in AFC after treatment with PRP, and this increase was statistically extremely significant with p-values of $<0.0001$ in each of the studies. This is shown in Table 3 .

Again in the study by Cakiroglu et al. [19], the average of pretreatment and post-treatment values of antral follicle count were found to be $0.5 \pm 0.5$ and $1.7 \pm 1.4$ indicating a statistically significant increase $(\mathrm{p}$-value $=$ $<0.01)$.

\section{Outcomes of the ICSI Cycle}

Sfakianoudis et al. compared the post-PRP ICSI cycle with the prior ICSI cycle as control [21]. They found the average of total number of retrieved oocytes ( $3.37 \pm 1.54$ versus $1.20 \pm 0.76$; p-value-<0.0001), number of mature oocytes $(2.97 \pm 1.38$ versus $1.00 \pm 0.79$; p-value- $<0.0001)$, number of two-pronuclei embryos $(2.43 \pm$ 1.38 versus $0.73 \pm 0.52$; $p$-value- $<0.0001)$, number of cleavage stage embryos $(1.93 \pm 1.26$ versus $0.60 \pm 0.56$; p-value-<0.0001), and cancellation rate (30\% versus $63.3 \%$; p-value 0.0191 ) were better in the post-PRP ICSI cycle as compared to the control, which bore a statistically significant difference. The number of good quality embryos produced was also more in the post-PRP ICSI cycle but this difference was not statistically significant when compared with the controls.

Similarly in the study by Melo et al., the total number of retrieved oocytes (median value of 5.0 ranging from 2.0 to 9.0 versus the median value of 3.0 with a range of $0.0-6.0 ; p$-value- $<0.001$ ), fertilization rate (median value of 0.5 ranging from 0.33 -1.0 versus median value 0.5 ranging from $0.0-1.0$; $p$-value $<0.0001$ ), and the number of good quality embryos $(22 / 100$ versus $6 / 55$; p-value-<0.0001) were better in the post-PRP ICSI cycle compared to the control which bore a statistically significant difference (Table 4) [20]. 


\begin{tabular}{|c|c|c|c|c|c|c|c|c|c|}
\hline $\begin{array}{l}\text { SI } \\
\text { no. }\end{array}$ & Study & Participants & $\begin{array}{l}\text { Number of } \\
\text { retrieved } \\
\text { oocytes }\end{array}$ & $\begin{array}{l}\text { Number of } \\
\text { mature } \\
\text { oocytes }\end{array}$ & $\begin{array}{l}\text { Number of } 2 \\
\text { pronuclei } \\
\text { embryos }\end{array}$ & $\begin{array}{l}\text { Fertilization } \\
\text { rate }\end{array}$ & $\begin{array}{l}\text { Number of } \\
\text { cleavage stage } \\
\text { embryos }\end{array}$ & $\begin{array}{l}\text { Good quality } \\
\text { embryo (grade- } \\
\text { 1\&2) }\end{array}$ & $\begin{array}{l}\text { Cancellation } \\
\text { Rate }\end{array}$ \\
\hline & $\begin{array}{l}\text { Cakiroglu et } \\
\text { al., } 2020 \text { [19]. }\end{array}$ & - & $\begin{array}{l}1.81 \pm 1.30 \\
(\mathrm{~N}=100)\end{array}$ & $\begin{array}{l}1.47 \pm 0.76 \\
(\mathrm{~N}=93)\end{array}$ & $\begin{array}{l}1.24 \pm 0.49 \\
(\mathrm{~N}=82)\end{array}$ & $\begin{array}{l}55.8 \pm 29.1 \\
(\mathrm{~N}=82)\end{array}$ & $\begin{array}{l}1.18 \pm 0.39 \\
(\mathrm{~N}=82)\end{array}$ & - & - \\
\hline & \multirow{3}{*}{$\begin{array}{l}\text { Melo et al., } \\
2020 \text { [20]. }\end{array}$} & $\begin{array}{l}\text { Cases (PRP } \\
\text { infusion) } \mathrm{N}=22\end{array}$ & $\begin{array}{l}5.0(2.0-9.0) \\
(\mathrm{N}=22)\end{array}$ & - & - & $\begin{array}{l}0.5(0.33- \\
1.0)\end{array}$ & - & $22(100)$ & - \\
\hline & & $\begin{array}{l}\text { Controls } \\
(\mathrm{N}=18)\end{array}$ & $3.0(0.0-6.0)$ & - & - & $0.5(0.0-1.0)$ & - & $6(55)$ & - \\
\hline & & P-Value & $<0.001$ & - & - & 0.51 & - & 0.03 & - \\
\hline & \multirow{3}{*}{$\begin{array}{l}\text { Sfakianoudis } \\
\text { et al., } 2020 \\
\text { [21]. }\end{array}$} & $\begin{array}{l}\text { Cases (Post- } \\
\text { PRP ICSI } \\
\text { Cycle) }\end{array}$ & $3.37 \pm 1.54$ & $2.97 \pm 1.38$ & $2.43 \pm 1.38$ & - & $1.93 \pm 1.26$ & 28/58 (48.2\%) & $9 / 30(30 \%)$ \\
\hline & & $\begin{array}{l}\text { Controls (Prior } \\
\text { ICSI cycle) }\end{array}$ & $1.20 \pm 0.76$ & $1.00 \pm 0.79$ & $0.73 \pm 0.52$ & - & $0.60 \pm 0.56$ & 8/18 (44.4\%) & $\begin{array}{l}19 / 30 \\
(63.3 \%)\end{array}$ \\
\hline & & P-Value & $<0.0001$ & $<0.0001$ & $<0.0001$ & - & $<0.0001$ & 0.7945 & 0.0191 \\
\hline
\end{tabular}

\section{TABLE 4: Outcomes of the ICSI cycle}

ICSI: intracytoplasmic sperm injection; PRP: platelet-rich plasma

In the study by Cakiroglu et al., ART was attempted in 201 women who had at least one antral follicle after PRP out of which oocyte retrieval was performed in 130 (64.7\% were stimulated) women [19]. Out of this, in 82 women (40.8\% of stimulated cycles), at least one cleavage-stage embryo was obtained and embryo cryopreservation or fresh embryo transfer was performed. These embryos were grade $1 / 2$ morphologically. The mean number of oocytes per retrieval was $1.81 \pm 1.30$. The mean numbers of two-pronuclei $(2 \mathrm{PN})$ and cleavage-stage embryos obtained in women who developed embryos were $1.24 \pm 0.49$ and $1.18 \pm 0.39$, respectively. Among the 82 women who developed embryos, 25 preferred to store cryopreserved embryos for transfer at a later stage and 57 underwent embryo transfer. Of those who underwent embryo transfer, 28/57 (49.1\%) were fresh embryo transfers and 29/57 (50.9\%) were frozen-thawed embryo transfers; 7/28 (25.0\%) of fresh embryo transfers and 6/29 (20.7\%) of frozen-thawed embryo transfers resulted in a pregnancy (Table 4).

\section{Discussion}

This systematic review involved the data analysis of 663 subfertile women who were intervened with an intra-ovarian infusion of PRP from four studies. PRP intervention was found to be beneficial in terms of improvement in ovarian reserve parameters (increase in serum AMH or antral follicle count or decrease in serum FSH). The outcome of the ICSI cycle was studied in three out of four included studies. The outcome of the ICSI cycle in terms of the total number of oocytes retrieved, number of two-pronuclei embryos, fertilization rate, number of cleavage stage embryos, number of good quality embryos, and cycle cancellation rate were found to be improved after the intra-ovarian PRP infusion as compared to their previous cycle without PRP infusion.

A study by Cakiroglu et al. found that women who did not have an antral follicle at the time of PRP injection were less likely to respond to treatment as compared to those who had one or two antral follicles [19]. Similarly, women with the lowest quartile for serum AMH and the highest for serum FSH were less likely to respond. The final conclusion for the same study was that PRP helps activate existing preantral and/or early antral follicles and that the number of remaining follicles in the ovaries of women with POI likely determines the extent of their response [19]. However, at this point in time, we cannot generalize this finding and there is an obvious need for future well-controlled studies to identify the subpopulation that can get the maximum benefit from PRP infusion.

Many studies have documented that the use of PRP can reduce the features of inflammation, postoperative blood loss, infection, and narcotic requirements. Also, PRP has a role in the acceleration of osteogenesis and wound and soft tissue healing [23-24]. The granules in platelets contain certain important growth factors such as transforming growth factor- $\beta$, insulin-like growth factors 1 and 2 (IGF-1 and IGF-2), vascular endothelial growth factor (VEGF), epidermal growth factor (EGF), basic fibroblast growth factor, and hepatocyte growth factor (HGF), which forms the basis for the tissue regenerative properties of PRP [17,25- 
These are the same growth factors that are considered to be vital for cell migration and differentiation, as well as for proliferation, activation of angiogenesis, and tissue regeneration [27-28]. Of note, studies have found an inverse relationship between aging and concentrations of growth hormone and IGF-1 [29].

Specifically, the application of PRP in ovarian rejuvenation has not been studied in detail. Till now, only a few studies have addressed this issue [30]. In their study, Bakacak et al. found that PRP can have a significant effect on preventing ischemia and reperfusion damage in rats following bilateral adnexal torsion and surgical detorsion [31]. They concluded that this action was mainly through an increase in VEGF. Few studies in the form of case series got encouraging results after evaluating the application of PRP for managing a thin endometrium, recurrent implantation failure, and poor response to controlled ovarian stimulation [32-34].

A case was reported documenting a biochemical pregnancy and subsequent miscarriage following autologous PRP intra-ovarian infusion in an infertile woman with premature ovarian failure [35]. Similarly, cases documenting live birth in poor responders following PRP infusion have also been reported [32]. Additionally, other studies support a contribution of PRP treatment to follicular growth and maturation [36].

Similar to our study, recently, a few case series also highlighted the efficacy of intra-ovarian PRP injection. In the case series described by Pantos et al. [37], Sills et al. [38], and Sfakianoudis et al. [32], the pretreatment serum AMH was increased after the intra-ovarian infusion of PRP. However, this increase in serum AMH levels was statistically significant only in the study by Pantos et al. [37] (p-value 0.0395), and in the studies by Sfakianoudis et al. [32] and Sills et al. [38], the difference was statistically not significant (p-values 0.4546 and 0.17 , respectively).

Similarly, in these case series, the pretreatment serum FSH values were decreased after the intra-ovarian infusion of PRP [32,37-38]. This decrease was found to be statistically significant in all of the above studies with p-values of $0.0310,0.01$, and 0.0053 , respectively.

In their case series, Pantos et al. found a post-treatment increase in the mean values of AFC $(0 \pm 0$ and $2 \pm$ 1.41, respectively) [37]. However, this was not found to be statistically significant with a p-value of 0.0699 .

\section{Strengths and limitations}

This is a systematic review evaluating the effect of intra-ovarian infusion of PRP on ovarian reserve parameters and ICSI cycle performance in women with decreased ovarian reserve or premature ovarian failure. However, some limitations should be considered in the interpretation of this systematic review. The less number of studies $(n=4)$ and lack of homogeneity among the included studies is the foremost limitation. This is the reason that we could not perform a meta-analysis. In most of the studies, pregnancy characteristics, such as clinical pregnancy rate, miscarriage rate, chemical pregnancy rate, and live birth rate have not been evaluated. Only a few studies have evaluated the ICSI cycle performance. Lastly, most of the included studies are quasi-experimental studies and not a single RCT is included. However, as the intraovarian infusion of PRP is a rare and the newest form of therapy in the field of infertility, such limitations are expected while conducting a systematic review. Moreover, the encouraging result of our study has paved the way for conducting future, well-organized, randomized controlled trials.

\section{Conclusions}

Our systematic review showed that intra-ovarian autologous PRP infusion increases the ovarian reserve parameters resulting in increased mature oocyte yield, fertilization rate, as well as the formation of goodquality embryos. Thus, this sensational novel therapy is particularly a great finding in the field of reproductive medicine, as this has the potential to put a full stop to our long search for the question of poor ovarian reserve and getting a genetically linked baby. Definitely, there is a great need for future, high-quality randomized controlled trials to estimate its efficacy in terms of clinical pregnancy and live birth rate. Also, there is a need to identify an optimum level of serum AMH or another marker of ovarian reserve for the success of intra-ovarian PRP infusion and identify the subpopulation that would get the most benefit from PRP.

\section{Appendices}




\section{Cureus}

\begin{tabular}{|c|c|c|c|c|c|c|c|c|}
\hline $\begin{array}{l}\text { Study } \\
\text { Domain }\end{array}$ & $\begin{array}{l}1 \\
\text { Confounding } \\
\text { Domain }\end{array}$ & $\begin{array}{l}2 \text { Selection of } \\
\text { Participants } \\
\text { Domain }\end{array}$ & $\begin{array}{l}3 \text { Classification of } \\
\text { interventions } \\
\text { Domain }\end{array}$ & $\begin{array}{l}4 \text { Departure From } \\
\text { intended interventions } \\
\text { Domain }\end{array}$ & $\begin{array}{l}5 \text { Missing } \\
\text { Data } \\
\text { Domain }\end{array}$ & $\begin{array}{l}6 \text { Measurements of } \\
\text { Outcome Domain }\end{array}$ & $\begin{array}{l}7 \text { Selection of } \\
\text { Reported } \\
\text { Results }\end{array}$ & $\begin{array}{l}\text { Overall } \\
\text { Judgment }\end{array}$ \\
\hline $\begin{array}{l}\text { Cakiroglu } \\
2020 \text { [19] }\end{array}$ & Low risk & Low risk & Low risk & Low risk & Low risk & Low risk & Low risk & Low risk \\
\hline $\begin{array}{l}\text { Melo } 2020 \\
\text { [20] }\end{array}$ & Low risk & Low risk & Low risk & Low risk & Low risk & Low risk & Low risk & Low risk \\
\hline $\begin{array}{l}\text { Sfakianoudis } \\
2020 \text { [21] }\end{array}$ & Low risk & Low risk & Low risk & Low risk & Low risk & Low risk & Low risk & Low risk \\
\hline $\begin{array}{l}\text { Sills et al. } \\
2020 \text { [22] }\end{array}$ & Low risk & Low risk & Low risk & Low risk & Low risk & Low risk & Low risk & Low risk \\
\hline
\end{tabular}

TABLE 5: Results of critical appraisal

\section{Additional Information}

\section{Disclosures}

Conflicts of interest: In compliance with the ICMJE uniform disclosure form, all authors declare the following: Payment/services info: All authors have declared that no financial support was received from any organization for the submitted work. Financial relationships: All authors have declared that they have no financial relationships at present or within the previous three years with any organizations that might have an interest in the submitted work. Other relationships: All authors have declared that there are no other relationships or activities that could appear to have influenced the submitted work.

\section{References}

1. Seli E: Ovarian aging. Semin Reprod Med. 2015, 33:375-376. 10.1055/s-0035-1567817

2. American College of Obstetricians and Gynecologists Committee on Gynecologic Practice and Practice Committee: Female age-related fertility decline. Committee opinion no. 589 . Fertil Steril. 2014, 101:633634. 10.1016/j.fertnstert.2013.12.032

3. Battaglia DE, Goodwin P, Klein NA, Soules MR: Influence of maternal age on meiotic spindle assembly in oocytes from naturally cycling women. Hum Reprod. 1996, 11:2217-2222. 10.1093/oxfordjournals.humrep.a019080

4. Collins GG, Rossi BV: The impact of lifestyle modifications, diet, and vitamin supplementation on natural fertility. Fertil Res Pract. 2015, 1:11. 10.1186/s40738-015-0003-4

5. Bahadori MH, Sharami SH, Fakor F, Milani F, Pourmarzi D, Dalil-Heirati SF: Level of vitamin E in follicular fluid and serum and oocyte morphology and embryo quality in patients undergoing IVF treatment. J Family Reprod Health. 2017, 11:74-81.

6. Tamura H, Takasaki A, Taketani T, et al.: The role of melatonin as an antioxidant in the follicle . J Ovarian Res. 2012, 5:5. 10.1186/1757-2215-5-5

7. Gat I, Blanco Mejia S, Balakier H, Librach CL, Claessens A, Ryan EA: The use of coenzyme Q10 and DHEA during IUI and IVF cycles in patients with decreased ovarian reserve. Gynecol Endocrinol. 2016, 32:534-537. 10.3109/09513590.2015.1137095

8. Özcan P, Fıçıcıŏ̆lu C, Kizilkale O, Yesiladali M, Tok OE, Ozkan F, Esrefoglu M: Can coenzyme Q10 supplementation protect the ovarian reserve against oxidative damage?. J Assist Reprod Genet. 2016, 33:1223-1230. 10.1007/s10815-016-0751-z

9. Ruder EH, Hartman TJ, Blumberg J, Goldman MB: Oxidative stress and antioxidants: exposure and impact on female fertility. Hum Reprod Update. 2008, 14:345-357. 10.1093/humupd/dmn011

10. Showell MG, Mackenzie-Proctor R, Jordan V, Hart RJ: Antioxidants for female subfertility. Cochrane Database Syst Rev. 2017, 7:CD007807. 10.1002/14651858.CD007807.pub3

11. Holloway D: Menopause symptom management in the United Kingdom . Nurs Clin North Am. 2018, 53:263277. 10.1016/j.cnur.2018.01.004

12. Lamarche $\mathrm{C}$, Lévy $\mathrm{R}$, Felloni $\mathrm{B}$, et al.: Prise en charge en Assistance médicale à la procréation des femmes de 38 ans et plus: résultats d'une enquête à propos de 84 couples. Assisted reproductive techniques in women aged 38 years or more [Article in French]. Gynecol Obstet Fertil. 2007, 35:420-429. 10.1016/j.gyobfe.2007.02.028

13. Remohi J, Vidal A, Pellicer A: Oocyte donation in low responders to conventional ovarian stimulation for in vitro fertilization. Fertil Steril. 1993, 59:1208-1215. 10.1016/s0015-0282(16)55978-0

14. Sauer MV, Paulson RJ, Lobo RA: Pregnancy after age 50: application of oocyte donation to women after natural menopause. Lancet. 1993, 6:321-323. 10.1016/0140-6736(93)90132-z

15. Silber SJ, Lenahan KM, Levine DJ, et al.: Ovarian transplantation between monozygotic twins discordant for premature ovarian failure. N Engl J Med. 2005, 353:58-63. 10.1056/NEJMoa043157

16. Rafique S, Sterling EW, Nelson LM: A new approach to primary ovarian insufficiency . Obstet Gynecol Clin North Am. 2012, 39:567-586. 10.1016/j.ogc.2012.09.007 
17. Amable PR, Carias RB, Teixeira MV, da Cruz Pacheco I, Corrêa do Amaral RJ, Granjeiro JM, Borojevic R: Platelet-rich plasma preparation for regenerative medicine: optimization and quantification of cytokines and growth factors. Stem Cell Res Ther. 2013, 7:67. 10.1186/scrt218

18. Sterne JA, Hernán MA, Reeves BC, et al.: ROBINS-I: a tool for assessing risk of bias in non-randomised studies of interventions. BMJ. 2016, 12:4919. 10.1136/bmj.i4919

19. Cakiroglu Y, Saltik A, Yuceturk A, et al.: Effects of intraovarian injection of autologous platelet rich plasma on ovarian reserve and IVF outcome parameters in women with primary ovarian insufficiency. Aging. 2020, 12:10211-10222. 10.18632/aging.103403

20. Melo P, Navarro C, Jones C, Coward K, Coleman L: The use of autologous platelet-rich plasma (PRP) versus no intervention in women with low ovarian reserve undergoing fertility treatment: a non-randomized interventional study. J Assist Reprod Genet. 2020, 37:855-863. 10.1007/s10815-020-01710-z

21. Sfakianoudis K, Simopoulou M, Grigoriadis S, et al.: Reactivating ovarian function through autologous platelet-rich plasma intraovarian infusion pilot data on premature ovarian insufficiency, perimenopausal, menopausal, and poor responder women. J Clin Med. 2020, 9:1809. 10.3390/jcm9061809

22. Sills E, Sills E, Petersen J, Rickers N, Wood S, Li X: Regenerative effect of intraovarian injection of activated autologous platelet rich plasma: serum anti-mullerian hormone levels measured among poor-prognosis in vitro fertilization patients. International Journal of Regenerative Medicine. 2020, 1:5. 10.31487/j.RGM.2020.01.02

23. Na JI, Choi JW, Choi HR, Jeong JB, Park KC, Youn SW, Huh CH: Rapid healing and reduced erythema after ablative fractional carbon dioxide laser resurfacing combined with the application of autologous plateletrich plasma. Dermatol Surg. 2011, 37:463-468. 10.1111/j.1524-4725.2011.01916.x

24. Park HB, Yang JH, Chung KH: Characterization of the cytokine profile of platelet rich plasma (PRP) and PRP-induced cell proliferation and migration: Upregulation of matrix metalloproteinase- 1 and -9 in HaCaT cells. Korean J Hematol. 2011, 46:265-273. 10.5045/kjh.2011.46.4.265

25. Sánchez-González DJ, Méndez-Bolaina E, Trejo-Bahena NI: Platelet-rich plasma peptides: key for regeneration. Int J Pept. 2012, 2012:532519. 10.1155/2012/532519

26. Ramaswamy Reddy SH, Reddy R, Babu NC, Ashok GN: Stem-cell therapy and platelet-rich plasma in regenerative medicines: a review on pros and cons of the technologies. J Oral Maxillofac Pathol. 2018, 3:367374. 10.4103/jomfp.JOMFP 9318

27. Borrione P, Gianfrancesco AD, Pereira MT, Pigozzi F: Platelet-rich plasma in muscle healing. Am J Phys Med Rehabil. 2010, 89:854-861. 10.1097/PHM.0b013e3181f1c1c7

28. Kingsley CS: Blood coagulation; evidence of an antagonist to factor VI in platelet-rich human plasma . Nature. 1954, 17:723-724. 10.1038/173723a0

29. Fanciulli G, Delitala A, Delitala G: Growth hormone, menopause and ageing: no definite evidence for 'rejuvenation' with growth hormone. Hum Reprod Update. 2009, 15:341-358. 10.1093/humupd/dmp005

30. Dawood AS, Salem HA: Current clinical applications of platelet-rich plasma in various gynecological disorders: an appraisal of theory and practice. Clin Exp Reprod Med. 2018, 45:67-74. 10.5653/cerm.2018.45.2.67

31. Bakacak M, Bostanci MS, İnanc F, et al.: Protective effect of platelet rich plasma on experimental ischemia/reperfusion injury in rat ovary. Gynecol Obstet Invest. 2016, 81:225-231. 10.1159/000440617

32. Sfakianoudis K, Simopoulou M, Nitsos N, et al.: A case series on platelet-rich plasma revolutionary management of poor responder patients. Gynecol Obstet Invest. 2018, 84:99-106. 10.1159/000491697

33. Chang Y, Li J, Chen Y, Wei L, Yang X, Shi Y, Liang X: Autologous platelet-rich plasma promotes endometrial growth and improves pregnancy outcome during in vitro fertilization. Int J Clin Exp Med. 2015, 8:12861290.

34. Nazari L, Salehpour S, Hoseini S, Zadehmodarres S, Ajori L: Effects of autologous platelet-rich plasma on implantation and pregnancy in repeated implantation failure: a pilot study. Int J Reprod Biomed. 2016, 14:625-628.

35. Sfakianoudis K, Simopoulou M, Nitsos N, et al.: Autologous platelet-rich plasma treatment enables pregnancy for a woman in premature menopause. J Clin Med. 2019, 8:1. 10.3390/jcm8010001

36. Hosseini L, Shirazi A, Naderi MM, et al.: Platelet-rich plasma promotes the development of isolated human primordial and primary follicles to the preantral stage. Reprod Biomed Online. 2017, 35:343-350. 10.1016/j.rbmo.2017.04.007

37. Pantos K, Simopoulou M, Pantou A, et al.: A case series on natural conceptions resulting in ongoing pregnancies in menopausal and prematurely menopausal women following platelet-rich plasma treatment. Cell Transplant. 2019, 28:1333-1340. 10.1177/0963689719859539

38. Sills E, Rickers N, Li X, Palermo G: First data on vitro fertilization and blastocyst formation after intraovarian injection of calcium gluconate-activated autologous platelet rich plasma. Gynecol Endocrinol. 2018, 34:756-760. 10.1080/09513590.2018.1445219 